\title{
An analytical survey of chat reference services
}

Stephen Francoeur

Information Services Librarian, Baruch College New York, NY

This is a final edited version of :

Francoeur, S. (2001), “An analytical survey of chat reference services”, Reference Services Review, Vol 29 No. 3, pp. 189-203.

\begin{abstract}
There has been in recent years a surge of interest about new software products that make it possible for libraries to offer assistance to online users via chat. Such software offers far more interactivity than instant messaging programs and allow for a richer experience for both librarian and user. Surveys chat reference services around the globe and analyzes trends in the provision of this new mode of assistance. Also presents discussion of why chat reference service is gathering attention as well as its limitations and drawbacks.
\end{abstract}

\section{Introduction}

As noted by many during presentations on digital reference at a recent conference of academic librarians, reference librarians feel that it is finally their turn to have something to talk about (and maybe even brag about). In the past decade or so, reference librarians have looked on as catalogers have had their moment in the spotlight with cooperative cataloging and metadata, instruction librarians made waves after they developed learning outcomes for information competency, and systems librarians gained prestige and attention as they hooked up their libraries with an ever-expanding set of electronic resources designed for the end-user. But now, with the aid of some clever software appropriated from the world of e-commerce, reference librarians have something to show off: software that lets them communicate with users online and in real-time via chat.

Although the concept of offering reference service online (digital reference) has been around since the mid-1980s, when libraries first started offering e-mail reference (Gray, 2000), it has been only four years since the first libraries tried chatting online with their users (Sloan, 2001). It has been an even shorter time since libraries started using more sophisticated software that allowed them not only to chat with their users but also to control fully their users' Web browsers. This more feature-rich software is commonly called Web contact center software (or sometimes customer relationship management software, a name that belies the origin of the technology in the world of e-commerce). It is the rapidly expanding use of this software in libraries that has generated considerable interest in the world of reference services.

In April 2001, I analyzed chat reference services being offered at libraries around the world. Based on this analysis, I will detail what kinds of libraries are providing the

This article is ( ) Emerald Group Publishing and permission has been granted for this version to appear here (http://arizona.openrepository.com/arizona/handle/10150/105067). Emerald does not grant permission for this article to be further copied/distributed or hosted elsewhere without the express permission from Emerald Group Publishing Limited. 
service and how many there are; what software they are using; what consortial arrangements they have created so that costs and workloads can be shared; and what can (and more importantly, cannot) be accomplished using currently existing technology. I will also include insights from my experience in planning, launching, and maintaining a chat reference service. Highlighted in this discussion will be an exploration of the history behind the trend toward these services and what conditions make it likely that a new chat reference service will succeed at a library.

\section{What chat reference looks like}

Before delving into a discussion of why chat reference projects are being launched in increasing numbers, it is worth describing what can be done with the technology now and where it is likely headed. For the purposes of this article, digital reference (or online reference or virtual reference) will be used to mean the provision of reference assistance via the Internet. E-mail reference is used here to describe services where the user is simply given an e-mail address to which to send questions as well as those services where the user is presented with a detailed Web form to be filled out and sent by means of a button click. Chat reference is meant to refer to those services where the core of the communication between librarian and user is an exchange of text messages sent in realtime using either basic chat technology like AOL Instant Messenger or ICQ or complex Web contact center software like NetAgent or eGain Interact.

Although there are other modes of digital reference that have been tried out recently (such as videoconferencing) or are currently being tested (such as collaborative reference services like as the Library of Congress's CDRS project), this article will focus primarily on chat reference.

\section{Survey of libraries providing chat reference}

As part of the process of planning the launch of a chat reference service at the academic library where I work, I began in August 2000 to gather data on how other libraries were offering such a service, noting such things as:

- type of library;

- software used;

- hours of service

- whether the library offered the service as part of a consortium;

- policies about the service (who could use it, what kinds of questions it would try to answer, etc.).

I learned about the existence of most of these services from messages on key mailing lists (Dig_Ref and LiveReference), journal and magazine articles, endless searches of Google for chat reference" or for the names of specific chat software packages, and from Web sites offering links to chat services. After I put up my own personal Web site with links to chat reference services, I started to hear from librarians around the country who wanted to tell me about their library's chat service and to suggest I add a link to it. 
At the time that the Newman Library at Baruch College launched its chat reference service on 1 March 2001, I created a Microsoft Access database to store data about these new services. Keeping up with new services is a struggle, as they tend to launch nearly every week. Counting the number of libraries offering chat reference is complicated by the fact that in most instances libraries have developed their own stand-alone services, but in other instances a group of libraries has pooled their resources to create one centralized service that provides assistance to the consortium. An example of the latter can be found in the Suffolk County Cooperative Library System in New York, in which patrons of 54 public libraries are served by one chat reference service. For the purposes of this analysis, I am only counting those chat reference services that were in operation as of April 2001. There is a far larger number of libraries of which I am aware that had plans to launch their services later in the year; these services have not been included in this analysis.

At the time of the survey, a total of 272 libraries were being served by a chat reference service, 210 of which (77 percent) were served by one of eight chat reference consortia. In most cases, a consortium is set up to serve the same set of users who have access to member libraries in that consortium. For example, anyone who has access to one of 17 public libraries of the NOLA Regional Library System can also use the consortium's chat reference service, which is known as AskUsQuestions.com An exception to this model can be found in the case of the Florida Distance Learning Reference and Referral Service, which is a consortium serving only students enrolled in distance learning courses at 73 public and private colleges and universities in Florida. Campus libraries at three of those 73 schools also run their own chat reference services designed to serve all the students of their respective campuses.

An interesting trend in how public libraries offer chat reference is that no public libraries are attempting to run a chat reference without the assistance of a consortium, usually a regional library system to which they already belong. In fact, of the 210 libraries served by reference consortia 57 percent $(n=120)$ are public libraries. Given the strong tradition of cooperative arrangements in general among public libraries, this trend in chat reference consortia is really not that surprising.

Despite the large number of public libraries served by chat reference consortia, the majority of the libraries served by chat reference services (54 percent, $n=148$ ) were academic libraries. Public libraries make up 45 percent $(n=122)$ of the total, while the one government library and the one special library only make up 1 percent. The total number of separate chat reference services (the number of consortia services added to the number of independent services serving just one library) is 70 . Of those 70 chat reference services, 90 percent $(n=63)$ serve academic libraries, 7 percent $(n=5)$ serve public libraries, and the remaining 3 percent represents the single special library and the single government library.

A caveat about the statistics for special libraries needs to be made. Although many kinds of special libraries (museum libraries and institute libraries, for example) do have Web

This article is ( ) Emerald Group Publishing and permission has been granted for this version to appear here (http://arizona.openrepository.com/arizona/handle/10150/105067). Emerald does not grant permission for this article to be further copied/distributed or hosted elsewhere without the express permission from Emerald Group Publishing Limited. 
sites, other kinds do not (particularly corporate libraries and law libraries). Finding out whether corporate and law libraries have chat reference services is a topic that needs further research.

\section{Software used for chat reference}

Before discussing what kinds of libraries with chat reference are using which software packages to run their chat reference services, it is worth presenting some background on the software. There are three categories of software being used in libraries today: chat, Web conferencing, and Web contact center software. There is also a fourth technology that libraries have been using to offer chat reference: a designated chat room for their library in a commercially provided Web site, such as Anexa.com, ChatSpace.com or Yahoo! Clubs. In this model, a library sets up a public chat room that users enter at predefined service hours and look for a librarian in the room with whom to chat. Only three libraries are currently operating their services in this way.

The most straightforward software used is chat software, which comes in two varieties. The first kind requires both the user and the library to download the software on their computer (usually free) and install it on their hard drive before they can begin chatting. This group of products includes such popular programs as AOL Instant Messenger, ICQ, and Netscape Chat. For a description of how the library at the University of Colorado at Boulder used ICQ in a test project, see Yue's (2000) presentation at the Virtual Reference Desk Conference.

The other kind of simple chat programs require only that the library install the software on their computers; the user merely has to click on an icon for the service on the library Web page, and a chat window will pop up on the user's screen without any downloads on the user's part. This group of products includes Camden, which Temple University Libraries created and started using in November 1999 (Stormont, 2000); WebMaster's ConferenceRoom, which is used by the Florida Distance Learning Reference and Referral Center (Ault and Viggiano, 2000); and Docutek's Virtual Reference Librarian, which is an add-on module for their popular DocuLib software that facilitates electronic reserve services.

These simple chat programs only allow for real-time exchange of text messages between user and librarian. Their simplicity and their low cost (they are often free) make them attractive to libraries interested in experimenting with chat reference on a small scale. Using software like AOL Instant Messenger and ICQ has the additional benefit in that many users have already downloaded it on their computers and use it regularly to exchange messages with family and friends. The downside of such software, though, is the limited kind of interaction available between user and librarian.

One library, Macquarie University in Australia, is currently using Web conferencing software: Microsoft's NetMeeting. Not only can users chat with librarians, they can also

This article is ( ) Emerald Group Publishing and permission has been granted for this version to appear here

(http://arizona.openrepository.com/arizona/handle/10150/105067). Emerald does not grant permission for this article to be further copied/distributed or hosted elsewhere without the express permission from Emerald Group Publishing Limited. 
see each other if both have Webcams, they can exchange ideas in an online whiteboard, and they can transfer files to one another. The University of Edinburgh also seems to use Web conferencing software, but it is not clear which product they are using. The drawback of this kind of software is that users must download and install a large program before they can use the library's service (although Microsoft does include NetMeeting in Windows 2000). Users may also have to spend time tinkering with the installation to ensure a successful connection to their library. The Web sites of the libraries at Macquarie University and the University of Edinburgh have lengthy instructions for users about installing and using the software, which is a bit of a disincentive for users.

The third category of software is the one that is generating the most interest in the library world and has been the subject of many articles and presentations: Web contact center software (Anderson et al., 2000; Breeding, 2001; Broughton, 2001; Coffman, 1999, 2001; Coffman and McGlamery, 2000; Eichler and Halperin, 2000; Helfer, 2001; Keiter and Porter, 2001; McGlamery and Coffman, 2000; Oder, 2001; Saunders, 2001; Schneider, 2000; Sloan, 2001). Products that libraries are currently using include eGain's Interact and eGain's Live; LivePerson and HumanClick (which are both owned by the same company, LivePerson); International Business System's LiveAssistance; LiveHelper; Convey System's OnDemand; and eshare's NetAgent. The software from eGain is unique in that two other organizations, one a private company (Library Systems and Services, Inc.) and one library cooperative (the Metropolitan Cooperative Library System's 24-7 Reference Project) have licensed eGain software, mounted on their own servers, and have made modifications to it to help adapt it to the library world's needs.

This modification points to a larger issue with Web contact center software: none of it was originally designed to help libraries run chat reference services. In fact, such software arose to meet the need of e-commerce to provide live customer service on the Web. Over the past decade, companies had invested heavily in building call centers where customers can use their telephones to receive customer assistance. When the era of online merchandizing got under way in the mid-1990s, businesses saw a need to provide help to those customers already on their Web sites. Early contact center software, such as Webline, not only allowed customers to chat online with a company representative, they could also release control of their browser to the rep, so that they could be guided through a company's Web site to appropriate pages or even have forms filled out for them by the rep as they looked on. Such software was designed so that online customer service reps had a way to hold customers' hands" and to help ensure the closing of an online sale (Wagner, 2001, p. 40).

Web contact center software packages each come with a different collection of features that take them well beyond what simple chat and Web conferencing programs can offer. Some products offer a few key features, while others costing much more provide a full range of tools for interaction between operator and caller. Although this software was designed to assist operators (customer service reps) and callers (customers), much of the functionality of it works on the librarian/user model as well.

This article is @ Emerald Group Publishing and permission has been granted for this version to appear here 
The most popular feature allows for the librarian to push Web pages on to the user's screen. On more sophisticated software, this feature works in both directions: the librarian can push pages to the user and the user can push pages to the librarian. This twoway page pushing is usually referred to as collaborative browsing, escorted browsing, or co-browsing. Collaborative browsing effectively synchronizes the browser of the user and the librarian, so that whatever one person does on the Web will be visible to the other user.

Another aspect of collaborative browsing is that it allows one person (either the librarian or the user) to fill out a form on a Web page that they are both viewing in their browsers (such as search query box in a search engine or proprietary database). This feature is commonly known as form sharing.

Some products also offer the same whiteboarding feature that is common on Web conferencing software. This tool is particularly useful for when the interaction involved more than two people and allows for group collaboration (such as one librarian providing instruction to a group of users that are expected to participate and offer ideas during the course of the instruction). Other features are also available in some products that allow for group instruction, such as chat sessions where a group can all participate in a mass chat session led by one librarian or even have online slide presentations beamed at them by the librarian.

To save the librarian typing time, most products allow for the creation of canned responses (also known as pre-formatted responses) from which the librarian can select and send to the user's chat window with a simple mouse click. Such canned responses can include instructions that are frequently sent (for example, how to connect to databases from off-site) or even standard questions used in reference interviews.

So that the librarian may be able to tell if a user has visited the service before, some products offer a user recognition feature. The first time a user visits the chat service, a cookie is placed on their computer. When that user returns to the service, the librarian can see on what date that user last visited the service and even the transcripts of prior chat sessions.

Many of the products also allow the librarian to search through archives of the transcripts for prior chat sessions. This can allow for evaluation of the chat service, but it also raises some privacy issues that will be discussed later in this article.

Another popular feature is one that allows the librarian to instantly e-mail the user the transcript of a just completed chat session (provided that the user has supplied an e-mail address). If users know that they will have a written record of their chat sent to them, they are freed from taking notes as they chat. Also, any URLs of pushed or co-browsed pages are included in the e-mail as active links, which allows users to click on the URL from within their e-mail programs and load the Web page on their browsers.

Another feature is file sharing, which some instant messaging programs also allow. It allows the librarian to send files (in a wide range of file formats) to users. Things that

This article is (C) Emerald Group Publishing and permission has been granted for this version to appear here (http://arizona.openrepository.com/arizona/handle/10150/105067). Emerald does not grant permission for this article to be further copied/distributed or hosted elsewhere without the express permission from Emerald Group Publishing Limited. 
could be sent include instruction guides, policy statements, video tours of a library, audio files, and more.

HumanClick is unique among Web contact center software for its feature that allows the librarian to monitor visitors on the library's Web site. The librarian can even send users an icon that floats across their browser screen, inviting the user to chat if help is needed. This is the closest equivalent in the world of chat reference to roving reference. As users enter a Web page encoded with Java script provided by HumanClick, a bell sounds on the chat reference librarian's computer, indicating that a user is there. The librarian can only see limited information about users on these monitored pages: on what IP address they are coming in, what browser they are using, how long they have been on the page, and whether that person has had a chat session in the past with the library.

Another feature that holds much promise for chat reference services is call transferring, which allows a librarian to pass a chat session along to a colleague if necessary. More sophisticated products allow for an administrator to route chat requests to available librarians or even to librarians with a particular subject specialty. Another way that routing by specialty could work is by allowing the user to enter the subject area to which their question relates and let the system route the call to an appropriate librarian. In this scenario, there is the danger that users will not be the best judges of the subject area to which their question pertains, a problem noted by Carter and Janes (2000) in their analysis of the Internet Public Library's e-mail reference service.

The ability of Web contact software to create queues of waiting users is another helpful feature. Librarians can keep tabs on how long particular users have been waiting for a chat and can make sure that they offer assistance to users in the order in which they requested it. Most systems send an automated message to the user, letting them know that his or her request for a chat has been received and that a librarian will respond shortly.

Some software even sends automated messages to the user during the chat session, if the librarian has not sent a message in a while (Eichler and Halperin, 2000). Such messages reassure the user that the librarian is working on the question and will get back in a moment.

Other products have searchable FAQs and knowledge bases that can be filled by the library with previously answered questions (Coffman, 2001; Oder, 2001). Because information coming in (questions) and information going out (answers and replies) are in text format, it is easy to capture and store in a knowledge base. If you make the knowledge base easily accessible and highly visible to users on your library Web site, you can cut down on the number of requests for information that is frequently sought after (such as how the user can access databases remotely, what the hours of the library are, etc.).

Users of some of these software systems can also be sent automatic satisfaction surveys. The software also provides tools that allow librarians to analyze and evaluate use of the service and the results of surveys.

This article is ( ) Emerald Group Publishing and permission has been granted for this version to appear here

(http://arizona.openrepository.com/arizona/handle/10150/105067). Emerald does not grant permission for this article to be further copied/distributed or hosted elsewhere without the express permission from Emerald Group Publishing Limited. 
There are a few features available now for which users and librarians probably are not technologically ready but which will likely be the wave of the future. One such feature is voice-over Internet protocol (VoIP), which is just a long-winded way of saying that people can speak to one another via their Web connection. Web-based telephony (as VoIP is also sometimes called) is still a developing technology and not widely used yet. A similar feature allows for videoconferencing, which, as noted earlier in the discussion of Web conferencing software, requires technologically sophisticated users who already have a Webcam (for two-way video, that is). Sending video that is not jumpy or fuzzy also requires substantial bandwidth on both the user's and the librarian's end. While still not that widespread, it is reasonable to assume that, as it becomes more common, videoconferencing will provide an ideal way of communicating with users.

Most Web contact center software is used by libraries on the application service-provider (ASP) model, which means that the software is actually mounted on the servers of the company providing the software. In most cases, the library does not have to install any software on their servers or personal computers. There are a few exceptions to this. For example, HumanClick requires that you download and install a small piece of software on any PC that will be used as an operator's terminal. With any ASP service, all that an operator need do to connect up to the service is go to a particular Web page on the company's site and log on. In theory, you can use any computer with an Internet connection from anywhere in the world to serve as your operator terminal. The benefit of this model is that it makes it possible for libraries to offer a telecommuting option for their chat reference librarians. It also makes it easy to share the service with other libraries in a consortium.

\section{Survey of software being used by libraries}

Two of the eight chat reference consortia have chosen to use simple chat software (AOL Instant Messenger and ConferenceRoom). The other six consortia use Web contact software. It is not surprising that the majority of the libraries using the most expensive, feature-laden software packages purchased it through a consortium, so costs could be shared. For example, the versions of eGain software licensed and repackaged by Library Systems and Services, Inc. (LSSI) as the Virtual Reference Desk and by the 24-7 Reference Project are both quite expensive and used primarily by libraries in a consortium. Only a few libraries have purchased such top-of-the- line software on their own.

The most popular software is HumanClick, which is used by 21 libraries with stand-alone chat reference services and by one consortium (the Suffolk County Cooperative Library System). Given its low monthly cost of $\$ 89.50$ and that it does not require any set-up fees, it is not surprising that many libraries have chosen to try their first chat reference service using this inexpensive software. The next most popular software is Docutek's Virtual Reference Librarian, which is used by eight reference services, all of which are at academic libraries. Given that the software is actually an add-on module for the DocuLib

This article is ( ) Emerald Group Publishing and permission has been granted for this version to appear here

(http://arizona.openrepository.com/arizona/handle/10150/105067). Emerald does not grant permission for this article to be further copied/distributed or hosted elsewhere without the express permission from Emerald Group Publishing Limited. 
software that makes an electronic reserve system possible, it is not surprising that this product is only used in academia.

LSSI's Virtual Reference Desk is the next most popular product, which has two consortia and five stand-alone services using it. One notable feature of Virtual Reference Desk is that LSSI can provide for a fee its own reference librarians to staff a library's chat service during later hours or even to deal with an overflow of requests that a library might receive during its service hours. The seven member libraries of the 24-7 Reference Project with services currently in operation can also provide staffing for a library's chat service after hours.

AOL Instant Messenger is used in as many reference services as Virtual Reference Desk: seven in total (one consortium and six stand- alone services). LivePerson, whose parent company also owns HumanClick, is used by five chat services (one consortium and four stand-alone services). LiveAssistance and LiveHelper are each used by three chat services. NetAgent, another full-featured piece of Web contact center software, is used by only two reference projects: a consortium in Ohio and at the Smathers Library at the University of Florida.

It should be noted that this survey does not take into account the numerous messages on the Dig_Ref and LiveReference mailing lists, in which librarians have said that their library is looking into a particular piece of software or will soon launch their service with such-and-such product. The numbers used in this survey represent a snapshot of a moving target.

\section{The move toward digital reference}

The question of why libraries are moving toward digital reference services in general and chat reference in particular is interesting. Much of what has been written about digital reference since the late 1990s cites declining statistics for reference transactions as evidence that traditional reference (face-to-face encounters at a reference desk) is not working on some level for users anymore (Broughton, 2001; Coffman, 1999; Coffman and McGlamery, 2000; Helfer, 2001; Lipow, 1999a, b; Oder, 2001; Saunders, 2001; Tenopir and Ennis, 1998; Viles, 1999; Wilson, 2000). At the Newman Library at Baruch College, this concern was also mentioned as being one of the reasons why we first started to explore adding a chat reference service. An issue even more vexing than deciding whether reference transactions are really in decline is trying to figure out why the users are not coming to the desk anymore.

A cluster of related trends - the rise of databases designed for the end-user, the widespread availability of personal computers, and the exploding growth of the World Wide Web - is probably partially responsible for declining numbers of reference transactions. Much of the public uncritically believes in the myth of the power of Webconnected computers to serve up on-topic, relevant information with a minimum of effort. The efforts of advertisers and marketers for the likes of Lycos, Yahoo, and the rest have played a role in intensifying this belief. With such seemingly simple tools available

This article is (C) Emerald Group Publishing and permission has been granted for this version to appear here

(http://arizona.openrepository.com/arizona/handle/10150/105067). Emerald does not grant permission for this article to be further copied/distributed or hosted elsewhere without the express permission from Emerald Group Publishing Limited. 
to them in their homes and offices, it is no wonder that many users bypass the library or use it as a place of last resort when searching for information. What reference librarian has not heard the tale of woe at the reference desk from the user who tried for hours to find some piece of information on the Web that could be easily found in a book in the library?

So if users are out in cyberspace struggling alone to find answers solely in online sources (especially those sources that are free on the Web), then it is worth wondering what is to become of libraries with their vast repositories of print. Who in the online world will advocate for libraries and their treasures? Lipow (1999a) notes that, if librarians are not online to assist users in cyberspace, then there is not likely to be anyone else there to recommend printed resources found only in a library. It does not seem reasonable to look to the commercial reference services on the Web (such as Webhelp.com, AllExperts.com, Exp.com, and Abuzz.com) to serve as champions of the holdings of local libraries, as they will most likely rely on suggesting online sources to their users.

Much of the literature on digital reference service mentions the sense of competition librarians are feeling from these commercial reference services (Breeding, 2001; Coffman and McGlamery, 2000; Guernsey, 2000; Heckart, 1999; Helfer, 2001; Lipow, 1999a, b; Oder, 2001; Peters, 2000; Schneider, 2000; Wilson, 2000). Users now have more options beyond the library for finding information. Included in the range of choices for the user are the free resources of the Web and the vast digital libraries that have been built since the mid-1990s. Librarians worked hard to increase access via the Web to their resources: pathfinders to print and electronic resources, digitized collections, OPACs and, lately, subscription databases.

Although it is laudable that librarians built these digital libraries for their users, libraries now need to be thinking about staffing them with actual human beings and providing live, interactive services for their users, a point often made in the literature (Breeding, 2001; Broughton, 2001; Gray, 2000; Helfer, 2001; Sloan, 1998a). If we went to all the trouble to erect these digital edifices, should not they too be staffed in some way? Peters (2000) argues that the evolution of digital libraries mirrors the evolution of traditional libraries: first came a focus on building collections, then cataloging and organizing those collections, and finally developing public services for the users of the library. Bannan (2000), writing about online customer service on e-commerce Web sites, cites a study by Jupiter Communications that also helps make the case for the need for libraries to reach out via live Web-based reference to their online users: 90 percent of people who shop online would prefer to have a human available on that Web site with whom to interact.

Part of the rapid growth of online reference services can be attributed to a growing sense among librarians that they need to reach out to their users and bring them back to the library, even if it is digital. Many librarians have noticed these trends that are pulling our users away from us and have explored ways to offer new services (if only as a way to defend the role of the library in society).

This article is ( ) Emerald Group Publishing and permission has been granted for this version to appear here 
But the growth of digital reference is not just a defensive maneuver to protect libraries from obsolescence. The literature suggests that users have real needs that cannot be adequately met through unassisted, end-user searching of online resources (both free and licensed) or from our commercial competitors on the Web. As the information landscape changes, so do the needs of our users. One of the more concise statements that puts these changes in perspective can be found in the comments made by Lipow (1999b) at a presentation in Australia: the user is not remote, it is the library that is remote from the user. Now that libraries are focusing on access to resources rather than just what is in their physical collections, there needs to be a shift in the service perspective of librarians that takes into account the realities of user needs.

One aspect of user needs that has been much noted is that users have an increased sense that they should be able to find things for themselves now that they have computers to assist them. Academic reference librarians surveyed by Tenopir and Ennis note that students expect to be able to answer every question and do every research project online" (Tenopir and Ennis, 2000, p. 85), a popular insight echoed by Gray (2000), Heckart (1999), Helfer (2001), Lipow (1999a, b), and Wilson (2000). But, as many have noted, as libraries provide more and more electronic resources for their patrons to access, users are getting more bewildered about where to begin searching or how to maneuver in each database (Broughton, 2001; Gray, 2000; Lipow, 1999a, b; Peters, 2000; Wilson, 2000).

One of the main selling points of chat reference is that it allows librarians to help right when the researcher needs the information" (McGlamery and Coffman, 2000, p. 380). Lipow (1999a) suggests that what libraries should be offering is an in your face' online reference service", one that users will not be able to overlook. Think of it as the online equivalent of roving reference. As noted earlier, HumanClick's Web contact center software offers just such a feature that allows the online user to sense that help from a librarian is immediate and nearby. This feature allows the librarian to see on the operator software the IP addresses of visitors to the library Web site. If the librarian so chooses, they can send an icon floating across a user's browser, inviting that user to click here for assistance".

There are also practical reasons why it makes sense to use online technology to assist our online patrons. Most users still access the Web with a dial-up connection. Without the option of chat reference, an online user in need of assistance is forced to disconnect their Internet connection just to call the library for help. Or the user must put off getting the help from a librarian until the next trip to the local library. As noted by Eichler and Halperin (2000), with a chat reference service available, users now have an increased number of options for communicating with their library and can request immediate assistance with the click of a mouse. This is obviously a great customer service advance for the user. It is worth mentioning Lipow's point (1999b) that people seeking information look primarily for convenience when selecting resources. If librarians are not readily available to online users, those users will quickly move on elsewhere to look for help.

This article is ( E) Emerald Group Publishing and permission has been granted for this version to appear here 
Another way that this issue of convenience plays out is that, even in a library where reference librarians are available, users can be hesitant to go to the desk for help because they fear losing their computer terminal, which they probably had to wait in line to use (Coffman and McGlamery, 2000; Lipow, 1999a, b; Saunders, 2001). As someone who has provided chat reference at an academic library, I can attest to this phenomenon. Not only have I chatted with users sitting at terminals only steps away from our library's reference desk, but I have also done so with users sitting in libraries at other colleges. With computer labs so prevalent on college campuses, chat reference service offers a way for the library to reach out to users beyond the building's walls. Chat reference may finally allow libraries to reach that group of users who would never consider asking for help at a library's reference desk. It may even allow libraries to reach out to those users who don't even set foot in the library because they feel they are entirely self-sufficient thanks to the Internet.

In her discussion of how libraries should plan their new digital reference services by taking into account the needs of today's computer- savvy user, Koyama (1998) discusses the characteristics of users for whom being online is second nature. She says that they may prefer the anonymity and freedom of the virtual environment to the experience of face-to-face encounters with reference librarians who get to control the interaction. Wilson (2000) suggests that technological change has altered the relationship between users and reference librarians. She argues that the users who avoided asking for assistance in libraries now have many convenient online options for seeking information on their own.

Wilson also makes the case that the patrons who are comfortable asking for help in the library and placing themselves in the role of supplicant" to the gatekeeper" librarian are ill served by this new online information world where user autonomy is prized. Digital reference service gives librarians a way of assisting both of these groups as needed in the online environment. There are other indications, mentioned by some (Anderson et al., 2000; Wilson, 2000), that users want the help of a librarian even if they are not coming in to the library to ask for it: online users are taking advantage of e-mail reference services in increasing numbers.

Academic libraries have also begun to consider the needs of students enrolled in distance education programs and have envisioned a vital role for digital reference services, especially as the numbers of such students increase. At the academic library where I work, one of the reasons cited by the chief librarian for why we would be experimenting with a chat reference service in the spring of 2001 was to prepare for the growing needs of distance learning students at our college. This sentiment is echoed in much that has been written about virtual reference service lately (Ault and Viggiano, 2000; Coffman, 2001; Helfer, 2001; Oder, 2001).

As a tireless advocate for virtual reference, Coffman (1999, 2001) has made the case that chat reference services can greatly improve efficiency in a library system where there are a central library and a number of branches. Because a chat reference service can be operated from a central office yet serve a cluster of libraries, a small group of librarians

This article is ( ) Emerald Group Publishing and permission has been granted for this version to appear here (http://arizona.openrepository.com/arizona/handle/10150/105067). Emerald does not grant permission for this article to be further copied/distributed or hosted elsewhere without the express permission from Emerald Group Publishing Limited. 
can provide online reference assistance to a large number of libraries, a point also made by Helfer (2001). Or as pointed out by Eichler and Halperin (2000), library staff can telecommute, since most packages allow librarians to log on to the service from anywhere. Lipow (1999a, b) and Schneider (2000) both see a centralized reference service to which libraries could subscribe so that reference hours could be extended without having to invest in staff, few of whom would likely be interested in working a graveyard shift anyway.

Other advocates for virtual reference have suggested that chat reference is becoming an attractive option as libraries recognize the limits of their e-mail reference services. Despite the popularity of e-mail services, many argue that it lacks immediacy and interactivity (Coffman and McGlamery, 2000; Helfer, 2001; Lipow, 1999a; McGlamery and Coffman, 2000; Sloan, 2001). Chat reference fills that void with instant messaging, co-browsing, file sharing, and much more.

Finally, it is likely that chat reference is gaining in popularity, because there is at last software that is up to the task of providing it. Simple chat programs like AOL Instant Messenger and ICQ were probably never going to be the best solution for chat reference services, given that they lack the ability to queue and route users as needed (McGlamery and Coffman, 2000). Without these features, chat software could never scale up to deal with the volume of demand that is likely in the future for this form of reference service. For small scale chat services (a single library serving a small community of users), basic chat programs do have their strengths, but for any large scale reference service (one serving more than a single library or where the library has a large staff of reference librarians and a large and active user population), Web contact center software offers the most promise.

\section{Understanding institutional conditions before launching a service}

There has been little written yet about how to plan, begin, and maintain a chat reference service. As a form of reference, it is just too new to have generated a large body of practical literature. Some authors have started to explore how a service can be planned and what conditions make it more likely that it will get off the ground. In the following section, I will review what others have suggested as well as describe our experience at Baruch College's Newman Library in starting the Ask A Librarian service.

First, there is a series of institutional considerations that should be explored during the planning process. Saunders (2001) and Sloan (1998b) note that a supportive administration is critical. The cost of software can be high, as will be the demands made on the staff who are expected to run the service and the systems staff who will likely be required to help sort out technical issues. Without the library administration backing up a project, coordinating the efforts of all the various departments involved becomes quite a challenge.

Another institutional concern is to make sure that the service being planned for fits in with the overall mission and goals of the library. If a written proposal is required to start

This article is ( ) Emerald Group Publishing and permission has been granted for this version to appear here (http://arizona.openrepository.com/arizona/handle/10150/105067). Emerald does not grant permission for this article to be further copied/distributed or hosted elsewhere without the express permission from Emerald Group Publishing Limited. 
the service, find and use language in the library's mission statement or strategic plan that is in line with how your chat reference service is envisioned. On a similar note, the service should probably be designed so that it is part of a seamless whole of reference options provided to users. The goals of the chat service should fit in with the overall philosophy of reference at your library. In an article about e-mail and video reference services, Sloan (1998b) also mentions the importance of getting the new service integrated into the library budget as a regular item.

\section{Understanding your users when planning a service}

Another critical consideration when planning is knowing who your users are. Decide whether your service will be open to all users who have access to your library or just a smaller portion. If your library is concerned about being overwhelmed with requests for the service just when it is starting up, consider restricting the service to a narrowly defined population. At Baruch College, our service is only open to Baruch community, even though the library itself is open to any student, faculty member, or staff member of the City University of New York (a system of 200,000 students at 20 campuses). Many of the other services at academic libraries are also restricted to immediate members of the campus. In some academic libraries, chat reference is offered only to students enrolled in distance education programs (as is the case with the chat services at the Florida Distance Learning Reference and Referral Center, Austin Community College, Indiana Wesleyan University, and Liberty University).

When considering user needs, it is useful to know what hours your patrons are likely to be online and interested in the service. While some chat services have escaped this dilemma by offering chat reference service around the clock, such as at North Carolina State University, and the Alliance Library System consortia serving eight academic libraries in Illinois, others have extremely limited hours so that they may get used to the service (two to three hours a day only). Most services offer hours in the afternoon and early evening; a smaller group of services also offer morning hours. At Baruch College, we expect to adjust our hours after an initial semester-long test of the service.

It is also helps to know what kinds of questions your users are likely to ask. One way to get a sense of what is of interest to users of remote reference services is to examine questions submitted to your e-mail reference service. The analysis by Carter and Janes (2000) of use of the e-mail reference service at the Internet Public Library suggests one way to go about discovering what sorts of questions online users have.

Your library will also want to know what percentage of your users have Internet access and what bandwidth they typically have. If your primary user population happens to be a college campus where the offices and dorms are wired for high-speed access, then you might be able to select one of the software products with a wide range of features that gobble up bandwidth (such as video conferencing or VoIP).

\section{Considering your staff when planning a service}

This article is (C) Emerald Group Publishing and permission has been granted for this version to appear here (http://arizona.openrepository.com/arizona/handle/10150/105067). Emerald does not grant permission for this article to be further copied/distributed or hosted elsewhere without the express permission from Emerald Group Publishing Limited. 
Important as it is to know your users when designing a service, it is also critical to understand your staff who will be asked to run the service. Depending on the complexity of the software product used, training may take a lot of time. For a staff that is less savvy with technology, a substantial amount of time for training may need to be set aside (Koyama, 1998; Saunders, 2001).

Your staff also needs to be flexible with doing reference in a new way (Wilson, 2000). As mentioned by Oder (2001), Sloan (1998b) and Straw (2000), staff members must be comfortable communicating in chat. At our library, while training staff members for the new service, I encouraged each one to chat with himself or herself by opening the operator end of the software on their computer and then in another browser window, clicking on the icon on the library page that patrons use to initiate a chat session. Although this is possible with HumanClick, some software products may not allow the operator to chat with himself or herself in this way. Staff members should also practice with each other before going live.

Many note that the staff must have an open attitude about technology in general (Stormont, 2000; Straw, 2000). Broughton (2001) and Oder (2001) both point out that staff members should feel comfortable multitasking on their computers (such as being able to toggle between a chat window, an OPAC screen, and a Web browser screen). If a library is using software that allows for co-browsing, there may be times during a reference transaction that a librarian will not want to sync up browsers with the user. For example, the librarian may want to do some preliminary searching and poking around in databases before getting back to the user with whom they are chatting. Staff members should probably have better than average online searching skills, as the pace of chat reference is faster and more pressured than in traditional reference work.

Your library should have a decent Internet connection and reasonably up-to-date software (Sloan, 1998b). It is also a good idea to have computers with sound cards and speakers, as many of the software products generate audio cues to indicate that a user has requested a chat or has just sent a text message in the chat window. In HumanClick, when the user closes the chat window, the HumanClick operator's software on the librarian's computer says "Adios" to signal that the chat has ended.

You will also need to decide where your staff will monitor the chat service. Unless your library has a quiet reference desk, it is probably not a good idea to expect your staff to do chat reference while also working at the desk. It is hard enough to keep users patient when they have to wait for a librarian already on the telephone at the reference desk; it is even trickier to do so when the librarian in an online chat session at the desk seems, to the user, to be just typing away on a computer.

It is also more likely that a chat reference librarian engaged in a chat at the desk will be overly distracted by a patron at the desk trying to get the librarian's attention. Serving users in the chat environment can be very intense and requires all your attention; the distractions of most reference desks will probably prove to be too great for most

This article is ( ) Emerald Group Publishing and permission has been granted for this version to appear here (http://arizona.openrepository.com/arizona/handle/10150/105067). Emerald does not grant permission for this article to be further copied/distributed or hosted elsewhere without the express permission from Emerald Group Publishing Limited. 
librarians. Librarians staffing the chat service at Baruch College typically close their doors during the time they are scheduled to monitor the service.

Of course, by not monitoring the chat service at the desk, you will need to create an additional schedule for staff. Finding enough staff to handle this new service point can be a challenge, a point made by Broughton (2001) in her description of launching a service at Bowling Green State University. One of the strengths of a chat service, though, is that libraries can team up to share the service hours, even if member libraries are separated by many time zones (Keiter and Porter, 2001; Lipow, 1999b; McGlamery and Coffman, 2000).

Another key consideration for planning a service is what standards of service should be followed. This is a topic of burgeoning interest in the digital reference field (Kasowitz et al.,2000; Oder, 2001), particularly with respect to how to maintain quality when a consortium of libraries are operating a single service.

Sloan (2001) made a number of useful points in his presentation at a recent Midwinter ALA meeting about the importance of how the user sees the service. He suggests that the links on the library's Web site to the service should be highly visible, that the terminology used to describe the service to the user be free of jargon, and that promotion is important. You cannot just build it and wait for them to come. Live online customer service is probably still a novelty to most customers in e-commerce sites, so it does not seem likely that it will occur to users to go looking for a chat reference service on the Web site of their local library.

In studying the Web sites of the 70 chat reference services, it was interesting to note that one of the most popular names for the service or the label for the link on the Web site to the service is Ask a Librarian". It is too early to tell if this naming convention will be the standard, but it does seem to be the front-runner for now among the service names.

\section{Problems with user interactions in the chat environment}

As with any new service in a library, it will take some time to work through all the problems. Some of the limitations are apparent now and others may only get noticed once more libraries have tried their hand at offering it. The issue most discussed relates to the nature of chat as a mode of communication. In chat, the lack of visual and audio cues that are normally available in face-to-face communication has been mentioned often (Broughton, 2001; Koyama, 1998; Straw, 2000; Viles, 1999). For the librarian in an online chat, it is not easy to pick up on the mood of the user, as there is no tone of voice to hear nor are there facial expressions and body language to interpret. The same limits apply, of course, for the user, who may not sense, for example, the enthusiasm the librarian has for the information request.

To the staff at Baruch College, some of whom had little or no experience chatting online, it was quite disorienting at first to conduct reference interviews by chat. It can take quite a bit of time for staff members to find their voice in this medium. An area that demands

This article is (C) Emerald Group Publishing and permission has been granted for this version to appear here

(http://arizona.openrepository.com/arizona/handle/10150/105067). Emerald does not grant permission for this article to be further copied/distributed or hosted elsewhere without the express permission from Emerald Group Publishing Limited. 
further research in the literature of librarianship is an analysis of what is gained and lost when communicating by chat as opposed to doing so face-to-face. A close analysis of the chat reference interaction that is informed by insights from the fields of communications, linguistics, cognitive science and psychology would be helpful.

One aspect of such communication seems quite clear. Users who ask for assistance via chat have high expectations of the service, can be impatient and demanding during the chat, and in general help to create a reference encounter that feels more pressured than is typical at a reference desk (Brandt, 2000; Peters, 2000; Schneider, 2000). Users in reference encounters can seem naive about how long it might take to satisfy their information needs. In a chat environment, where the reference interaction is slowed down by the typing of messages, users can lose patience. As I have seen numerous times in chat reference interactions, patrons sometimes abruptly terminate their chat sessions, a behavior also noted by Koyama (1998).

It may be the case that, in chat communication, there are fewer social expectations and niceties at work than in face-to-face interactions. While this freedom in the chat mode may be seen positively by the user (especially one who for any reason feels uncomfortable approaching a librarian at a reference desk), it may be viewed negatively by the librarian, who feels that the user has less commitment to the interaction than is appropriate and is uncooperative in participating in the back and forth of the reference interview.

Because users may be more impatient while in a chat engagement, librarians may have to work a little harder to reassure the user of the seriousness of their commitment to the user's need. Users may not understand why a librarian does not instantly reply to their every chat message. It is hard for the user to see that you might be actively working on the user's request, an insight noted by Oder (2001) and confirmed by our experience here at Baruch. At the reference desk, when a user asks you to help them and you then turn to your computer to try a few searches, the user can see that you are actually trying to help them. But in the chat mode, the user cannot see you working unless you have set your browser and the user's for co-browsing.

Unless the librarian and user are using a co-browsing feature, it can be a mystery to the librarian what the user is up to on the other end. The HumanClick software we use at Baruch College does not offer collaborative browsing, so, if we push a Web page to the user or if we talk them through doing a search, it is important that the user follows our every instruction. Otherwise, we have no clue as to what the user has done or whether they have properly followed our instructions.

Another problematic user behavior can be seen in the patron who, in the middle of a chat session, disappears without terminating the chat. It could be that the user has gotten up to answer the door or the telephone on a second line, but it is a challenge for the librarian to be left hanging like that. At our library, in such situations we send a series of messages to the user, asking if they is still there. If after a reasonable amount of time there is no response, we end the chat.

This article is ( ) Emerald Group Publishing and permission has been granted for this version to appear here (http://arizona.openrepository.com/arizona/handle/10150/105067). Emerald does not grant permission for this article to be further copied/distributed or hosted elsewhere without the express permission from Emerald Group Publishing Limited. 
Our staff has also found that the hardest kind of question to answer is one that requires a considerable amount of topic development and user instruction, a problem also discussed by Anderson et al. (2000) and Broughton (2001). This is particularly true for chat services with software that does not offer collaborative browsing, which makes it easier to take charge of the user's computer to show them something. Trying to walk a user through constructing a search strategy and through the mechanics of performing that search in a particular database is labor intensive and usually more efficiently done at the reference desk. In such cases at Baruch, we sometimes suggest that the user come in to the library's reference desk.

Another problem is related to the delicate matter of asking online users to come in to the library to look at a printed resource. Online users may be less interested in taking a librarian's suggestion to use a particular printed resource that the librarian knows best suits the user's information need. Given the common expectation among users that everything they need can be found online, it may be particularly hard to convince the patron otherwise, especially if that user is not in the library and cannot immediately follow up the librarian's suggestion. Libraries offering a chat service need to develop a policy delineating when and how they will refer patrons to the physical library.

As noted by Heckart (1999), Kasowitz et al. (2000) and Oder (2001), there are also a number of privacy issues in digital reference services that need to be worked out. Koyama (1998) discusses in particular the problems created by having user interactions stored or saved in some format. Not only should users be concerned about their privacy, but librarians need to consider whether chat transcripts or e- mail responses can be reviewed by supervisors and under what circumstances. Users may also not be comfortable knowing that data about their chat sessions are stored by the library (time of visit, IP address, browser used, etc.)

\section{Problems of technology}

Aside from the obvious problems that a user may have with a finicky Internet connection that cuts out unexpectedly or is slow, there are other things that can go wrong with the technological aspects of chat reference. For example, none of the software producers that I contacted when helping launch the service at Baruch College was able to tell me if their products worked with assistive software used by those who are blind or have low vision (such as screen readers like JAWS). In an article by Kasowitz et al. (2000) describing the evolving standards for quality service in digital reference consortia, one of the standards required for membership in the Virtual Reference Desk's AskA consortium is to maintain practice with the Americans with Disabilities Act (ADA)" (Kasowitz et al., 2000, p. 357). It is hoped that users who find getting to the library too physically difficult because of disabilities will be particularly interested in digital reference services. But if the technology we are using to offer those services is not ADA compliant, then we are effectively shutting out what could be a core constituency of users.

This article is (C) Emerald Group Publishing and permission has been granted for this version to appear here 
According to some reports (Coffman, 2001; Keiter and Porter, 2001), collaborative browsing still has some glitches, too. Not all Web pages or database pages can be pushed and, when some Web pages are co-browsed, the chat session is disconnected.

The software can also be very expensive, with some of the more expensive products costing several thousand dollars a month. Choosing a less expensive product, such as HumanClick, also means not having some of the most useful features, like collaborative browsing. And there is no guarantee that the company from which you bought the software will be around tomorrow. There are quite a few competing products on the market and it is likely that there will be a shake-out someday. Already, some of the companies have been bought out (for example, Cisco bought Webline and LivePerson acquired HumanClick). Aside from Docutek, which provides a chat product with limited functionality, none of the familiar names in library software has software yet for this use.

\section{Questions for further research}

The literature has not offered much yet in descriptions of information-seeking behavior in a totally online environment. Having such an understanding might assist librarians struggling with techniques and strategies for working with users in a chat environment. As elaborated by Peters (2000), we do not really have a good sense yet of what our users' needs are in this new information landscape. He argues that we may not even be able to fully imagine these needs yet, as each of us, user and librarian, is still adapting to the changes in the information environment. Both Peters (2000) and Tenopir and Ennis (1998) suggest that online reference librarians may find themselves helping users more with tasks that come up after information has been retrieved (evaluating it, manipulating it, sorting it, or storing it).

Another interesting research question is how libraries that are working together in a consortium or a less formal relationship to offer reference assistance to a shared group of users can guarantee standardized, quality service (Breeding, 2001; Keiter and Porter, 2001). Different libraries can have very different reference philosophies. It can also be an unending chore for librarians to keep up with changes in resources at other libraries in their consortium.

As we work together in consortia and gain more experience doing chat reference, it might be important to know if these new modes of service are reaching new groups of users, people who would normally pass up reference assistance at a library or might not even be library users to begin with. If these new services are indeed creating new library users, this surely would be one of digital reference's greatest triumphs.

\section{References}

Anderson, E., Boyer, J. and Ciccone, K. (2000), Remote reference services at the North Carolina State University libraries , available at: http://www.vrd.org/ conferences/VRD2000/proceedings/boyer-anderson- ciccone12-14.html (accessed 30 January 2001).

This article is ( ) Emerald Group Publishing and permission has been granted for this version to appear here

(http://arizona.openrepository.com/arizona/handle/10150/105067). Emerald does not grant permission for this article to be further copied/distributed or hosted elsewhere without the express permission from Emerald Group Publishing Limited. 
Ault, M. and Viggiano, R. (2000), "Going the distance: traditional reference services for non-traditional users”, Florida Libraries, Vol. 43 No. 2, Fall, pp. 6-7.

Bannan, K. (2000), "Chatting up a sale: online shopping sites use real-time rooms to aid customers”. Available at: http://www.wsj.com/public/current/articles/SB971800147663017706.htm (accessed 11 April 2001).

Brandt, D.S. (2000), "E-mail makes the world go round”, Computers in Libraries, Vol. 20 No. 10, November/ December, pp. 64-6.

Breeding, M. (2001), "Providing virtual reference service”, Information Today, Vol. 18 No. 4, April, pp. 42-4.

Broughton, K. (2001), "Our experiment in online, real-time reference”, Computers in Libraries, Vol. 21 No. 4, April, pp. 26-31.

Carter, D.S. and Janes, J. (2000), “Unobtrusive data analysis of digital reference questions and service at the Internet Public library: an exploratory study”, Library Trends, Vol. 19 No. 2, Fall, pp. 251-65.

Coffman, S. (1999), "Reference as others do it”, American Libraries, Vol. 30 No. 5, May, pp. 54-7.

Coffman, S. (2001), “Distance education and virtual reference: where are we headed?”, Computers in Libraries, Vol. 21 No. 4, April, pp. 20-25.

Coffman, S. and McGlamery, S. (2000), “The librarian and Mr Jeeves”, American Libraries, Vol. 31 No. 5, May, pp. 66-9.

Eichler, L. and Halperin, M. (2000), "LivePerson: keeping reference alive and clicking”, EContent, Vol. 23 No. 3, June, pp. 63-6.

Gray, S.M. (2000), "Virtual reference service: directions and agendas”, Reference \& User Services Quarterly, Vol. 39 No. 4, Summer, pp. 365-75.

Guernsey, l. (2000), “Suddenly, everybody’s an expert”, The New York Times, February 3, Section G, p. 1.

Heckart, R.J. (1999), “Imagining the digital library in a commercialized Internet”, Journal of Academic Librarianship, Vol. 25 No. 4, July, pp. 274-80.

Helfer, D.S. (2001), "Virtual reference in libraries: remote patrons heading your way?”, Searcher, Vol. 9 No. 2, February, pp. 67-70.

Kasowitz, A., Bennett, B. and Lankes, R.D. (2000), “Quality standards for digital reference consortia”, Reference \& User Services Quarterly, Vol. 39 No. 4, Summer, pp. 355-62.

Keiter, l. and Porter, G. (2001), "Hot topics discussion group”, RUSA Update, Vol. 22 No. 1, January/March, p. 13.

Koyama, J.T. (1998), “http://digiref.scenarios.issues”, Reference \& User Services Quarterly, Vol. 38 No. 1, Fall, pp. 51-3.

Lipow, A.G. (1999a), “In your face reference service”, Library Journal, Vol. 124 No. 13, August, pp. 50-52.

Lipow, A.G. (1999b), "Serving the remote user: reference service in the digital environment”. Available at: http://www.csu.edu.au/special/online99/proceedings99/200.htm (accessed 18 December 2000).

McGlamery, S. and Coffman, S. (2000), “Moving reference to the web”, Reference \& User Services Quarterly, Vol. 39 No. 4, Summer, pp. 380-86.

This article is ( ) Emerald Group Publishing and permission has been granted for this version to appear here

(http://arizona.openrepository.com/arizona/handle/10150/105067). Emerald does not grant permission for this article to be further copied/distributed or hosted elsewhere without the express permission from Emerald Group Publishing Limited. 
Oder, N. (2001), “The shape of e-reference”, Library Journal, Vol. 126 No. 2, February 1, pp. 46-50.

Peters, T.A. (2000), "Current opportunities for the effective meta-assessment of online reference services”, Library Trends, Vol. 49 No. 2, Fall, pp. 334-49.

Saunders, l. (2001), “Building the virtual reference desk”, Information Today, Vol. 18 No. 3, March, pp. 25-7.

Schneider, K.G. (2000), “The distributed librarian: live, online, real-time reference”, American Libraries, Vol. 31 No. 11, November, p. 64.

Sloan, B. (1998a), "Service perspectives for the digital library: remote reference services”, Library Trends, Vol. 47 No. 1, Summer, pp. 117-43.

Sloan, B. (1998b), "Electronic reference services: some suggested guidelines”, Reference \& User Services Quarterly, Vol. 38 No. 1, Fall, pp. 77-82.

Sloan, B. (2001), “Evaluating digital reference”, available at: http://www.lis.uiuc.edu/ bsloan/evaldigref.htm (accessed 10 April 2001).

Stormont, S. (2000), “Interactive reference project: assessment after two years”. Available at: http://www.vrd.org/conferences/VRD2000/proceedings/stormont.html (accessed 30 January 2001).

Straw, J.E. (2000), “A virtual understanding: the reference interview and question negotiation in the digital age”, Reference \& User Services Quarterly, Vol. 39 No. 4, Summer, pp. 376-9.

Tenopir, C. and Ennis, l. (1998), “The impact of digital reference on librarians and library users”, Online, Vol. 22 No. 6, November/December, pp. 84-8.

Viles, A. (1999), 'Virtual reference interview: equivalences”. Available at: http://www.ifla.org/VII/dg/dgrw/dp99-06.htm (accessed 2 April 2001).

Wagner, H.J. (2001), “Chatting up customer service”, Customer Interface, Vol. 14 No. 2, February, p. 40.

Wilson, M.C. (2000), "Evolution or entropy? Changing reference/user culture and the future of reference librarians”, Reference \& User Services Quarterly, Vol. 39 No. 4, Summer, pp. 387-90.

Yue, J. (2000), “The use of ICQ in providing real time reference services”. Available at http://www.vrd.org/conferences/VRD2000/proceedings/Yue11-20.html (accessed 30 January 2001). 